\title{
Freshwater ecosystems of the southern region of the russian far east are undergoing extreme environmental change
}

\author{
V.V. Bogatov ${ }^{1}$ and A.S. Fedorovskiy ${ }^{2, \star}$ \\ ${ }^{1}$ Institute of Biology and Soil Science, Far East Branch, Russian Academy of Sciences, pr. 100-letiya Vladivostoka 159, 690022 Vladivostok, \\ Russia \\ ${ }^{2}$ Far Eastern Federal University, ul. Sukhanova 8, 690950 Vladivostok, Russia
}

Received April 19, 2016 - Revised June 20, 2016 - Accepted June 28, 2016

\begin{abstract}
The freshwater ecosystems of the Southern Region Of the Russian Far East (SRORFE) are subject to the influence of environmental extremes (especially heavy floods and droughts). Within forested areas, extreme floods do not destroy the ecosystems of rivers and floodplain lakes; in contrast, periodic medium and small floods alternating with low-flow periods are beneficial to these ecosystems. In the 21 st century, the natural flood cycles will change, likely increasing the peaks of floods but decreasing the probability of rain during the dry season. Extreme floods can lead to the rapid depletion of river phytoplankton and zoobenthos and can cause long-term water hyper-eutrophication. Droughts will increase the probability of forest fires. The loss of forest cover due to logging and fires will intensify the unsteadiness of hydrological regimes of water bodies. In the SRORFE global environmental change, accompanied by increasing anthropogenic pressures and a lack of protective measures will cause a significant loss of biodiversity among freshwater biota. Meanwhile, forest preservation will ease the negative effects on the biodiversity and productivity of freshwater ecosystems in the SRORFE.
\end{abstract}

Key-words: freshwater ecosystems / global warming environmental extremes / eutrophication / forest fires

Résumé - Les écosystèmes d'eau douce de la région sud de l'Extrême-Orient russe subissent des changements environnementaux extrêmes. Les écosystèmes d'eau douce de la région du sud de l'Extrême-Orient russe (SRORFE) sont soumis à l'influence des conditions environnementales extrêmes (en particulier de fortes inondations et des sécheresses). Dans les zones boisées, les inondations ne détruisent pas les écosystèmes des rivières et des lacs des plaines inondables; au contraire, de petites à moyennes inondations périodiques alternant avec des périodes de faible débit sont bénéfiques pour ces écosystèmes. Au $21^{\mathrm{e}}$ siècle, les cycles naturels d'inondation vont changer, avec probablement augmentation des pics d'inondations, mais diminution de la probabilité de pluie pendant la saison sèche. Les crues extrêmes peuvent conduire à l'épuisement rapide du phytoplancton et du zoobenthos de la rivière et peuvent causer à long terme l'hyper-eutrophisation de l'eau. Les sécheresses augmenteront la probabilité d'incendies de forêt. La perte de la couverture forestière en raison de l'exploitation forestière et des incendies intensifiera le déséquilibre des régimes hydrologiques des masses d'eau. Dans le SRORFE, les changements environnementaux mondiaux, accompagnés d'une augmentation des pressions anthropiques et de l'absence de mesures de protection entraînent une perte importante de la biodiversité dans les communautés d'eau douce. En même temps, la préservation des forêts va atténuer les effets négatifs sur la biodiversité et la productivité des écosystèmes d'eau douce dans le SRORFE.

Mots-clés : écosystèmes d'eau douce / réchauffement climatique / extrêmes environnementaux / eutrophisation / incendies de forêt

\section{Introduction}

The Southern Region Of the Russian Far East (SRORFE) is bordered by the Stanovoy Ridge to the north and by the Amur River, its right tributary the Ussuri River, Lake Khanka and the

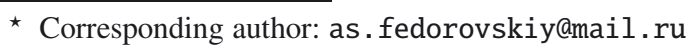

East Manchurian Mountains to the west and south. The eastern boundary of this region is formed by the Seas of Okhotsk and Japan (Figure 1). The study area is mainly mountainous, with plains and lowlands constituting less than $25 \%$ of its area, and is densely forested, with $70 \%$ forest cover (Rozenberg et al., 1993; Bogatov et al., 2000). The boreal forests of the Sikhote-Alin Ridge and East Manchurian Mountains are more 


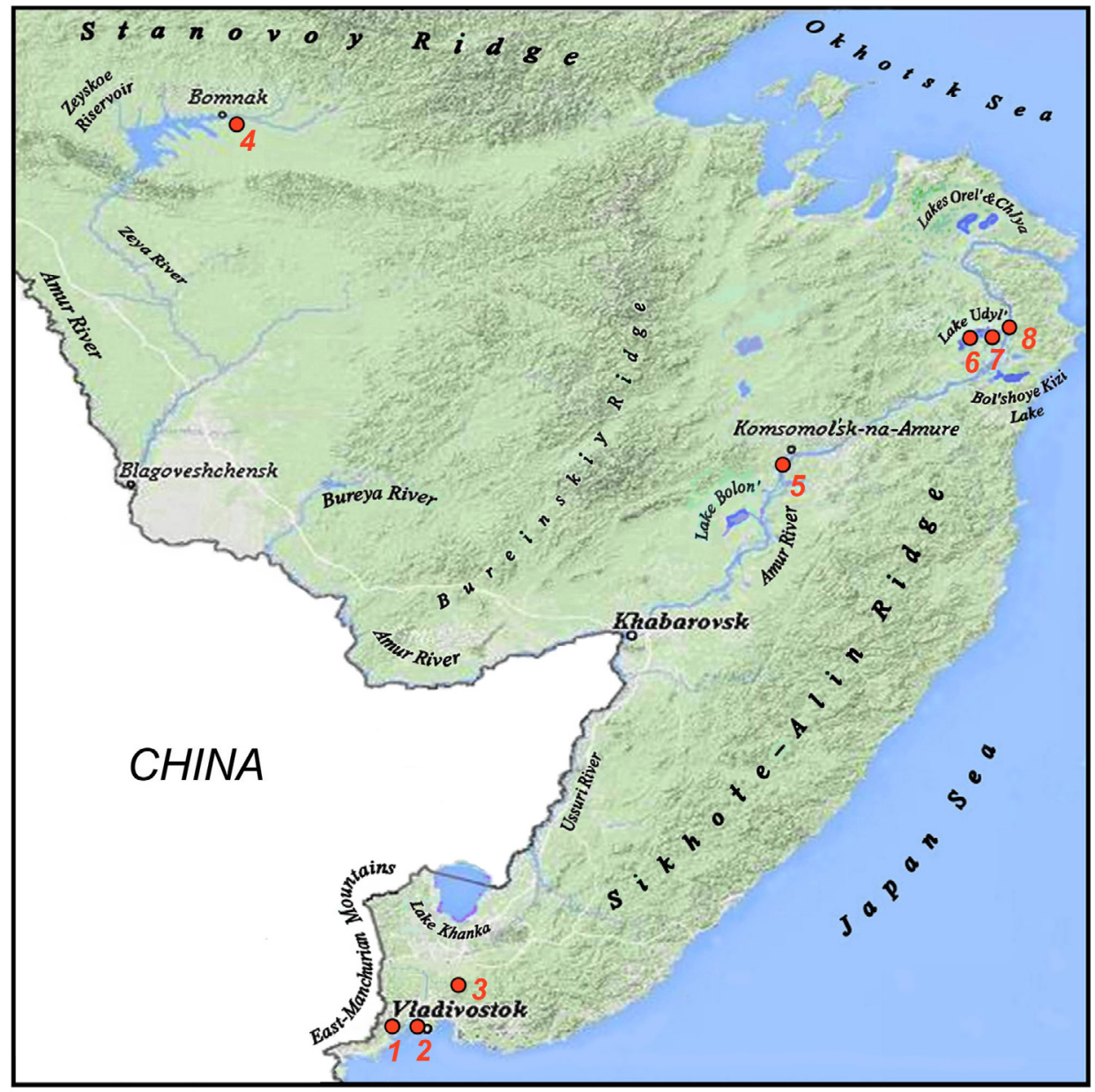

Fig. 1. Physical Geography of the Southern Region Of the Russian Far East. Red points and digits are the cites of log-term observations: 1 - Kedrovaya River, 2 - Sedanka River, 3 - Komarovka River, 4 - Bomnak River, 5 - the Amur River near Komsomol'sk-na-Amure town, 6 - Lake Udyl', 7 - Ukhta Channel, 8 - the Amur River near Bogorodskoe village.

diverse than all other regions of Russia in terms of species richness and of the variety and uniqueness of forest communities (Bogatov et al., 2000; Krestov et al., 2011).

The SRORFE lies in temperate latitudes in a zone with intense cyclonic activity and a distinct monsoon trend (Khromov, 1956; Fedorovskiy, 1985). Weakened tropical cyclones cause heavy floods, which usually occur in late summer to early autumn. Up to $80-90 \%$ of the annual precipitation occurs as rain. Therefore, the freshwater ecosystems of the region are under the influence of extreme environmental conditions (summerautumn floods and low winter precipitation) that define the characteristics of their structural-functional organisation.

Global warming has changed all the components of the climate system, including increasing the prevalence of climate extremes and changing the hydrological regimes (strengthening of flooding and elongation of low-water periods) (Yasyukevich et al., 2014). Anomalous high temperatures during the dry season usually result in large forest fires that can cause large-scale landscape deforestation and intensification of hydrological extremes.

It is impossible to preserve the biodiversity of regional freshwater ecosystems without considering the direction of their transformation due to the changing climate and landscapes, including an exploration of the behaviour of the population and distributions of aquatic organisms during extreme events.

The goal of our investigation is to explore the main feature of the structures and functions of freshwater ecosystems in a monsoon climate focusing on the reaction of aquatic communities to environmental extremes.

The main hypothesis of this work is that strengthening environmental extremes (flooding, low- water levels, etc.) due to changing climate and landscapes can cause the catastrophic degradation of freshwater communities, especially in mountain regions. At the same time, forest preservation can ameliorate the negative effects of these extremes on the biodiversity and productivity of freshwater ecosystems in the SRORFE and in regions with similar climates and landscapes.

\section{Materials and methods}

This investigation is based on field observation data on the dynamics of benthos and plankton communities during 1975-2015 in various parts of the SRORFE. The main sites are the downstream portion of the Amur River from the town 
of Khabarovsk to the mouth of the river (called the Lower Amur River); the downstream portion of the Bomnak River (right tributary of the Zea River, which is a left tributary of the Amur River); the middle stream of the Burea River (left tributary of the Amur River); the upstream portion of the Ussuri River (right tributary of the Amur River); the Razdol'naya (Suifun) River and the Kedrovaya River (outfalls to Amurskiy Bay in the Sea of Japan); the Komarovka River (left tributary of the Razdol'naya River); the Sedanka River and the upstream portion of the Vtoraya Rechka River, along the southeastern slope of Sikhote-Alin, near Vladivostok (the water protection area of the town of Vladivostok); and numerous streams in various parts of the Sikhote-Alin Ridge and East-Manchurian Mountains. Moreover, hydrobiological surveys were conducted in the floodplain lakes of the lower region of the Amur River: Lake Bolon', Lake Khummi, Lake Udyl', Bol'shoye Kizi Lake, Lake Orel', Chlya Lake and others (Figure 1).

To collect benthos invertebrates (to estimate the population density), we used Bogatov's folding benthometer (Institute of Biology and Soil Science, Far East Branch, Russian Academy of Sciences, Russia), an analogous benthometer of increased weight, and various scoop nets and drags (Alimov et al., 2013). Using the folding benthometer, we collected samples from deep areas of up to $0.6 \mathrm{~m}$ in depth; the increased-weight benthometer was used up to $1.0-1.2 \mathrm{~m}$ in depth. At each site, we accumulated at least four samples. The collected samples were washed through mesh (size $315 \mu \mathrm{m}$ ) and fixed in $2 \%$ formaldehyde or $70 \%$ ethanol. In the laboratory, zoobenthos samples were processed under an MBS-2 stereoscoping binocular microscope (Lytkarino Optical Glass Factory, Russia). In total, more than three thousand samples were assembled.

Planktonic organisms were collected using Molchanov's bathometer (Hydrometpribor, Russia). To gather and quantitatively estimate the amount of phytobenthos, we obtained 10-12 stones from the river bottom and brushed the algae off of them. Then, we estimated the area of the stones from their projection using the gravimetric method. The concentration of the photosynthetic pigment of algae was measured using a standard spectrophotometric method in $90 \%$ acetone extract (SCOR-UNESCO, 1966; Strickland and Parsons, 1968). Phytoplankton and periphyton, depending on the amount of algae, were concentrated by passing $0.02-1.0 \mathrm{~L}$ of water through the membrane filter. Immediately before filtration, the membrane filter was covered by a layer of crushed quartz glass prepared using Boulion's technique (Boulion, 1983). The algal cells were disrupted by three minutes of trituration in a pounder. The extracts were clarified by centrifugation. The concentration of chlorophyll $a(C h l-a)$ was calculated using the formula of Jeffrey-Humphrey (1975). The total data volume amounted to 900 estimations of the Chl-a concentration.

To determine the stream discharges, we used the "velocityarea" method. This method requires the area of a stream crosssection $-A\left[\mathrm{~m}^{2}\right]$ and the average stream velocity $-V\left[\mathrm{~m} \cdot \mathrm{s}^{-1}\right]$. Discharge $-Q\left[\mathrm{~m}^{3} \cdot \mathrm{s}^{-1}\right]$ is calculated as $Q=V \times A$. The area was calculated from a stream cross-sectional survey using a measuring tape and ruler and considering the water surface as a horizontal line. Velocity was measured using the propeller current meter GR 21M (Hydrometpribor, Russia). For the stream flow statistic, we used published data from the long-term observations of Roshydromet.

The regression analysis was performed in Microsoft Excel, using a "least squares" method to fit a line through a set of observations to analyse how a single dependent variable is affected by the values of an independent variable. We used the coefficient of determination, denoted $R^{2}$, to indicate how well the data fit a statistical model.

\section{Results}

\subsection{Freshwater hydrobionts}

The species composition of hydrobionts and their variety in surrounding stream and river communities are dependent on the distance from headwaters and, correspondingly, on hydrologic drainage features. Higher aquatic plants have not developed in mountainous streams because of the large variations in flow. Only at very few sites in floodplain lakes are small patches of Cyperaceae and other plants found. Phytoplankton and zooplankton are practically absent from the mountain or foothill regions of river channels. Here, the algal colonisation of stones provides the primary production. In the floodplain reaches of rivers, high depth, low water transparency and variable water levels hamper the development of periphyton communities. Most of the primary production is attributed to the photosynthetic activity of the phytoplankton. Approximately 941 species of algae are found in the Lower Amur River and its floodplain lakes (Medvedeva and Sirotskiy, 2002). Here, invertebrate communities include both benthic and plankton organisms. Among the most widely distributed plankton invertebrates are Cladocera, Copepoda and Rotatoria. The highest number and biomass of zooplankton are found after the springsummer floods. During this period, the zooplankton consist of more than 20 crustacean species. In winter, the zooplankton numbers in the lower region of the Amur River are very low and include only 2-3 species (Safonov, 1979).

Zoobenthic organisms reach their highest densities in the mountain and foothill parts of rivers; the most important of these organisms are larvae of insects of the orders Diptera, Ephemeroptera, Plecoptera, and Trichoptera (Levanidova, 1982). The order Diptera is represented mainly by larvae of Blephariceridae, Chironomidae, and Simuliidae. In streams and rivers with salmon runs, the larvae of these insects can constitute as much as $80-90 \%$ of the benthic biomass (Tiunova, 2006). In the mountain and foothill parts of forest streams (mainly of the 3rd and 4th orders) in the SRORFE, amphipods (Gammarus lacustris and G. coreanus) develop in large numbers, averaging approximately $10-40 \%$ of the number and biomass of the benthos. For decades (averaged for each season), all parts of the constant stream maintained the same ratio of these groups of hydrobionts. For example, in the foothill branch of the Kedrovaya River, with the mean annual zoobenthic biomass ranging from $20-30 \mathrm{~g} \cdot \mathrm{m}^{-2}$ (in natural weight), a hydrobiology study from the Institute of Biology and Soil Science (Levanidov, 1977; Kocharina et al., 1988, Bogatov, 1994; Tiunova, 2001) over two decades (from 1972 to 1993) reported a stable relationship between the main zoobenthic groups, with a prevalence of larvae of caddisflies 


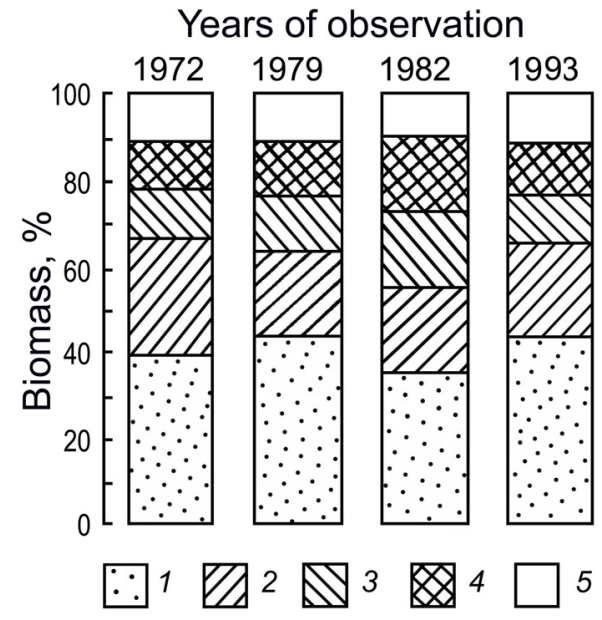

Fig. 2. The biomass of benthos (\% of wet weight) in the Kedrovaya River (East-Manchurian Mountains) in 1972-1993. 1972 - after: Levanidov (1977); 1979 - after: Kocharina et al. (1988); 1982 after: Bogatov (1994); 1993 - after: Tiunova (2001). 1 - caddisflies (Trichoptera); 2 - mayflies (Ephemeroptera); 3 - stoneflies (Plecoptera); 4 - amphipods; 5 - others.

(36-42\% of the mean annual biomass), mayflies (20-25\%) and stoneflies (12-20\%), as well as the amphipod $G$. coreanus (10-15\%) (Figure 2).

The river basins in the SRORFE are home to approximately 200 species of freshwater mussels, representing a quarter of the mussel species inhabiting the Russian Federation. Large colonies of bivalves, including Dahurinaia dahurica and Middendorffinaia mongolica, are widely distributed. The Lower Amur River Basin is inhabited by mollusc species of the genera Nodularia, Lanceolaria, Cristaria, Sinanodonta, Amuranodonta and Anaemina, representing the highest concentration of mollusc species in the Ussuri River Basin (Starobogatov et al., 2004).

More than 150 species of fish are found in freshwater ecosystems in the SRORFE, representing one-third of all the freshwater fish species in the Russian Federation (Bogutskaya et al., 2008; Bushuev and Barabanstchikov, 2012; Eschmeyer et al., 2016). In mountain and foothill streams, the most common fish species are graylings (Thymallus spp.), taimen (Hucho taimen), and lenoks (Brachymystax lenok and B. tumensis). The lower region of the Amur River is inhabited by the valuable sturgeons Acipenser schrenckii and Huso dauricus. Floodplain reaches and lakes contain golden carp (Carassius gibelio), Amur pike (Esox reichertii), carp (Cyprinus rubrofuscus), silver carp (Hypophthalmichthys molitrix) and Amur catfish (Silurus asotus), as well as the very rare species Aucha fish (Siniperca chuatsi), black Amur (Mylopharyngodon piceus), and snakehead (Channa argus). In midsummer and autumn, large schools of far-eastern salmon leave the Sea of Okhotsk and the Tatar Strait to enter the Amur River and its tributaries; these species include chum salmon (Oncorhynchus keta), pink salmon (Oncorhynchus gorbuscha), and masu salmon (Oncorhynchus masou). On the eastern slopes of the Sikhote-Alin Ridge, Sakhalin sturgeon (Acipenser mikadoi) and Sakhalin taimen (Parahucho perryi) enter the region's streams.

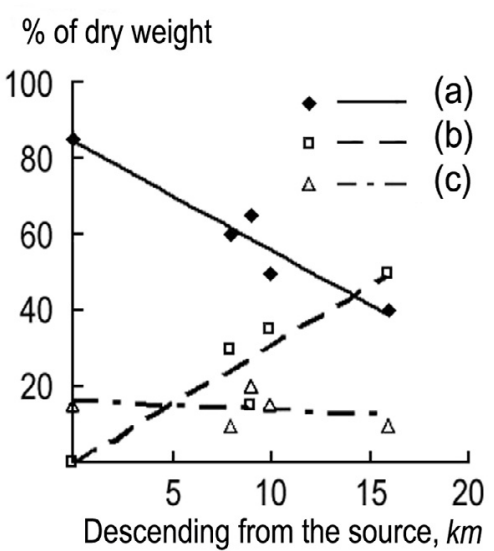

Fig. 3. The percentage of particulates (up to $1 \mathrm{~mm}$ ) of allochthonous and autochthonous organic matter (\% of dry weight) in the daily seston in the Sedanka River on October 12, 1991: (a) - allochthonous organic matter; (b) - autochthonous organic matter; (c) - exuvia fragments of benthic invertebrates exuviae.

\subsection{Formation of the river continuum}

Without flooding, stream systems continuously develop their structural and functional characteristics according to the river continuum concept (Vannote et al., 1980). In forested river basins worldwide, riverheads play a significant role in the biotic balance of allochthonous organic matter. Away from the riverheads, the ecosystem's organic balance becomes autochthonous. We observed such regularity when exploring the seston organic particle ratio of various origins. Specifically, the continuum of the Sedanka River (within the water protection zone of Vladivostok) showed consistent changes in the ratio of allochthonous to autochthonous seston. Here, in the late summer and fall of 1991, a study of the organic composition of seston showed that the proportion of demolished allochthonous organic matter (with suspended particles of up to $1 \mathrm{~mm})$ peaked in the riverhead $\left(R^{2}=0.91\right.$; Figure $\left.3 \mathrm{a}\right)$. Descending from the upper reaches to the river mouth, the seston become more dominated by autochthonous organic matter in the form of individual cells or bits of algae $\left(R^{2}=0.86\right.$; Figure $3 b)$. The proportion of exuviae from larvae of aquatic insects and amphipods in the seston along the whole length of the river consistently ranged from $10-20 \%$ of the total dry weight of the extract $\left(R^{2}=0.62\right.$; Figure $\left.3 \mathrm{c}\right)$.

In the upper zone of mixed conifer-broadleaf forests of the southwestern Sikhote-Alin Ridge, we discovered that the river inflow and the formation of multi-specific benthic communities are greatest when the watershed area is $60-70 \mathrm{~km}^{2}$. Both the morphohydrological characteristics of rivers and the taxonomic diversity of algae and invertebrates strictly depend on the size of the watershed area (Bogatov and Nikulina, 2010; Bogatov et al., 2010, 2013). A decreased rate of the taxonomic enrichment of hydrobiontic communities is observed farther downstream and indicates a certain boundary beyond which the lotic community passes into a different state that is characteristic of high-order river segments. The nutrient turnover in such segments is slower than that in lower-order rivers (Minshall et al., 1983), and the structural-functional characteristics of the biota change less abruptly (Bogatov, 1994). 

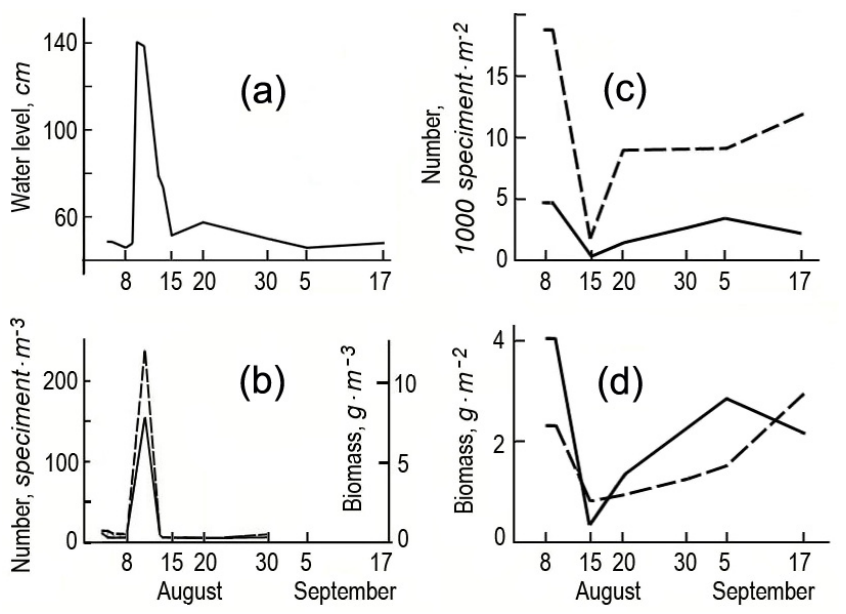

Fig. 4. Fluctuation of the water level (a), drift dynamics of benthic organisms (solid line is the number, dashed line is the biomass) in the surface layer of water (b), population dynamics (c) and biomass (d) of benthic macroinvertebrates of the stony bottom of Bomnak River, Middle Amur Basin (solid line - riffle, dashed line - pool).

Thus, the upper reaches of rivers (mainly of the 1st and 2nd orders) play a critical role in the formation of the riverine benthos community as a whole. These streams are the main drainage element of the river, collecting water from soil, diluvium, cavities and crevices in the bedrock, and, in some cases, the surface runoff from saturated parts of slopes and valley bottoms. Higher-order rivers ( $>2$ nd order) carry these waters away and mainly act as transportation elements within the overall river network. Subsequent changes in the benthic species composition within these transit river segments are defined less by the watershed area itself than by changes in the water depth, current, temperature, and conditions of solar insolation. These factors become especially important when mountain rivers reach the plains and when rheophilic communities are replaced by potamophilic communities.

\subsection{Floods}

The effect of variation in the mountain river regime on the dynamics of the benthos community was observed in the pool and riffle areas of the Bomnak River (right tributary of the Zeya River; the watershed area is approximately $490 \mathrm{~km}^{2}$ ) from August-September 1975. From August 9-14, a moderate flood with a water level increase of approximately $1 \mathrm{~m}$ was observed (Figure 4a).

Before the flood, the number of organisms in riffles was much lower, but their biomass was greater than that in pools. This difference in biomass was primarily the result of the development of large larvae in riffles, including those of the midges Gnus subvariegatum, Gn. cholodkovskii and Simulium vulgare and the caddisfly Glossosoma altaicum. At the peak of the flood, the number of organisms per cubic metre of the surface layer of water was 50 times higher and their biomass 25 times greater than before the flood (Figure 4b). After the flood, the drift of organisms decreased sharply, the number

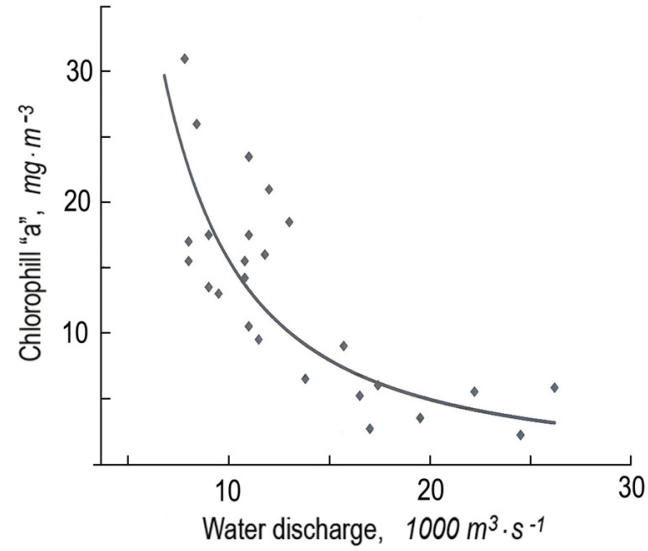

Fig. 5. Polynomial regression between the Chl-a concentration in Amur plankton and the water discharge in the Amur River near Komsomol'sk-na-Amure.

of organisms inhabiting the stones decreased 22-fold in riffles, and their biomass decreased 10-fold; in the pools, these decreases were less severe, at 11- and 3-fold, respectively (Figures $4 \mathrm{c}$ and $4 \mathrm{~d}$ ). Thus, the greatest changes in number and biomass during the flood occurred in riffles. For two months after the flood, the densities of organisms in the pool and riffle areas did not reach their initial values. In the middle of September, the biomass of hydrobionts was restored only in pools, basically at the expense of the growth of organisms (Figure 4d).

In the mountain and foothill parts of rivers, high and even moderate floods can reduce the phytobenthic and zoobenthic biomass by an order of magnitude. For example, in a stream of the 2nd order (Vtoraya Rechka River, southeastern slope of the Sikhote-Alin Ridge, near Vladivostok), the loss of biomass due to a moderate summer flood was equivalent to a $30 \%$ decrease in the annual production of invertebrates (Bogatov, 1994).

In lowland rivers, floods regulate the development of planktonic communities. For example, in the warm part of the year, the concentration of Chl- $a$ in Amur River plankton near the town of Komsomol'sk-na-Amure depends largely on the water flow, and in certain parts of the river, this relationship is markedly reversed $\left(R^{2}=0.697\right.$; Figure 5$)$. During floods, the $C h l-a$ concentration ranges from 1.5 to $6.0 \mathrm{mg} \cdot \mathrm{m}^{-3}$ and is rather uniformly distributed along a depth profile. During low-flow periods, the concentration of Chl- $a$ in different parts of the Lower Amur River is $8-30 \mathrm{mg} \cdot \mathrm{m}^{-3}$ and occasionally higher (Sirotskiy, 1986). The maximum concentration of Chl-a (20-40 $\left.\mathrm{mg} \cdot \mathrm{m}^{-3}\right)$ was found at various sites, including the mouth of the Ussuri River, the Amur River below Komsomol'sk-na-Amure, and the entrances to side channels connecting the Amur River with the large floodplain lakes that serve as the main source of phytoplankton.

The dynamics of the Chl- $a$ concentration in floodplain lakes during the flood periods is interesting. For example, in Lake Udyl', which is connected to the Amur River (near Bogorodskoe village) by the $12-\mathrm{km}$ Ukhta Channel, during a low-flow period (Figure 6a), when the flow from the lake enters the Amur River, the horizontal Chl-a concentration is uniformly distributed and reaches approximately $50-70 \mathrm{mg} \cdot \mathrm{m}^{-3}$; only in those places where mountain rivers enter the lake is 

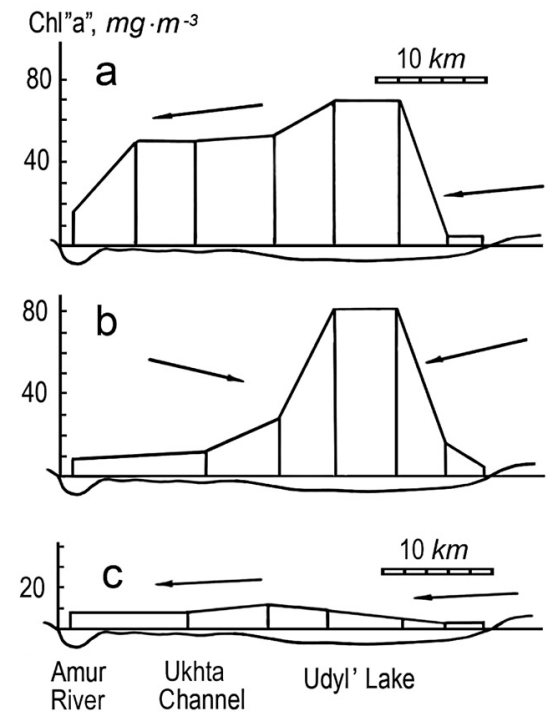

Fig. 6. Horizontal distribution of Chl- $a$ in Lake Udyl', at water levels of (a) $41 \mathrm{~cm}$ before flood; (b) $130 \mathrm{~cm}$ during flood; and (c) $59 \mathrm{~cm}$ after flood. The arrows show the direction of the stream.

the concentration usually below $10 \mathrm{mg} \cdot \mathrm{m}^{-3}$. During the flood period, when water from the Amur River enters the lakes, in those places where the river and lake water meet - that is, at sites where there is temporarily no flow - zones of high productivity are formed in which a mass development of algae is observed (Figure 6b). These mixed waters contain extremely high concentrations of Chl- $\mathrm{a}$ in the phytoplankton, exceeding $80 \mathrm{mg} \cdot \mathrm{m}^{-3}$ and the concentrations observed during periods of low flow. When the flood level decreases, the water from the lakes again enters the Amur River, the zone of high productivity disappears, and the horizontal distribution of the algae becomes uniform (Figure 6c). During this period, i.e., a period of an intense decrease in the water level of the lake, the concentration of Chl- $a$ in the lake flow decreases significantly and is usually not more than $10-15 \mathrm{mg} \cdot \mathrm{m}^{-3}$ (Bogatov et al., 1995). Thus, an important conclusion follows: stabilisation of hydrological regimes in floodplain lakes of the Lower Amur River causes sharp eutrophication.

\subsection{Eutrophication}

During prolonged periods of low water, an eutrophication process is a characteristic feature of the middle and lower reaches of rivers in the SRORFE. During low-snow winters, diatomaceous algae blossom sometimes even under ice cover (Figure 7a). After low-snow winters, the spring floods are very small, and the eutrophication process is extended further. Our observations show that after the high spring floods, the concentration of Chl-a within the periphyton of 3rd- to 4 th-order rivers ranges from $2-20 \mathrm{mg} \cdot \mathrm{m}^{-2}$; however, when a spring flood is very small, the concentration of Chl-a may reach $7000 \mathrm{mg} \cdot \mathrm{m}^{-2}$ (Bogatov, 1994). Extensive algal proliferation negatively affects young fish and populations of Ephemeroptera, Plecoptera and Trichoptera, while populations of Chironomidae thrive. During these periods, we observed a growth of periphyton (Figure $7 \mathrm{~b}$ ) or a formation of metaphyton communities within plains (Figure 7c).

In headwaters, riparian forest canopies partially or fully cover channels, and no extensive development of algae occurs. Here, the trophic relationships within benthic invertebrate communities become highly competitive because of a very limited amount of allochthonous organic matter that can reach the stream. Meanwhile, during periods of low water, headwaters that lost their forest cover are exposed to intense eutrophication (Figure 7d). An intense development of algae is explained by organic matter reaching the stream from biogenous elements being washed out from watershed soils.

A single flood can reverse this situation by washing out algal mats and dense leaf litter and by cleansing muddy sections of the channel. This eliminates the high mortality rate of invertebrates and fish and favours a fairly rapid (tens of days) development of diverse zoobenthic communities.

In floodplain lakes, the concentration of Chl- $a$ can range from 8 (right after a flood) to $260 \mathrm{mg} \cdot \mathrm{m}^{-3}$. During summer in still weather in all of the surveyed floodplain lakes, a close correlation between the $C h l-a$ concentration in plankton ( $C h l-a$, in $\left.\mathrm{mg} \cdot \mathrm{m}^{-3}\right)$ and water transparency $(S$, in $\mathrm{m})$ is observed and can be described by the equation:

$$
S=1.3 e^{-0.015 C h-a}, R^{2}=0.903,
$$

where $e$ is the natural logarithmic base, and 1.3 is a constant value showing the possible transparency of water in the absence of algae (Bogatov et al., 1995). This correlation indicates the uniformity of phytoplankton and the optical characteristics of the Amur River floodplain lakes. In addition, algal development increases as the water level of lakes decreases. The periods of the lowest level are accompanied by an abundant development of Cyanobacteria and are often followed by mass mortality of fish (Bogatov, 1994).

\section{Discussion}

The main feature of recent climate change is increased surface temperature in the late 20 th and early 21 st centuries. The mean annual anomalies in surface temperature for the Russian Federation (Figure 8) and the SRORFE (Figure 9) after 1976 show the most intense warming trend. Compared to the base period (1961-1990), the increase during 1976-2015 was approximately $0.43{ }^{\circ} \mathrm{C} / 10 \mathrm{yr}$ and $0.39{ }^{\circ} \mathrm{C} / 10 \mathrm{yr}$ for the country and the SRORFE, respectively (Bardin et al., 2016). Overall, climate change in Russia (including the SRORFE) should be characterised as extended warming at more than twice the rate of global warming (Yasyukevich et al., 2014; Bardin et al., 2016).

Due to climate change, environmental extremes are more frequent. The natural flood cycles will change by increasing the flood peaks and decreasing the probability of rain during the dry season (Moss, 2010; Strayer and Dudgeon 2010; Goldman et al., 2013; Yasyukevich et al., 2014). In the SRORFE, climate change is expected to cause considerable runoff in the form of increased summer-autumn floods. Variability in river flow, especially seasonally, was recently observed during periods of extremely high and low water. 

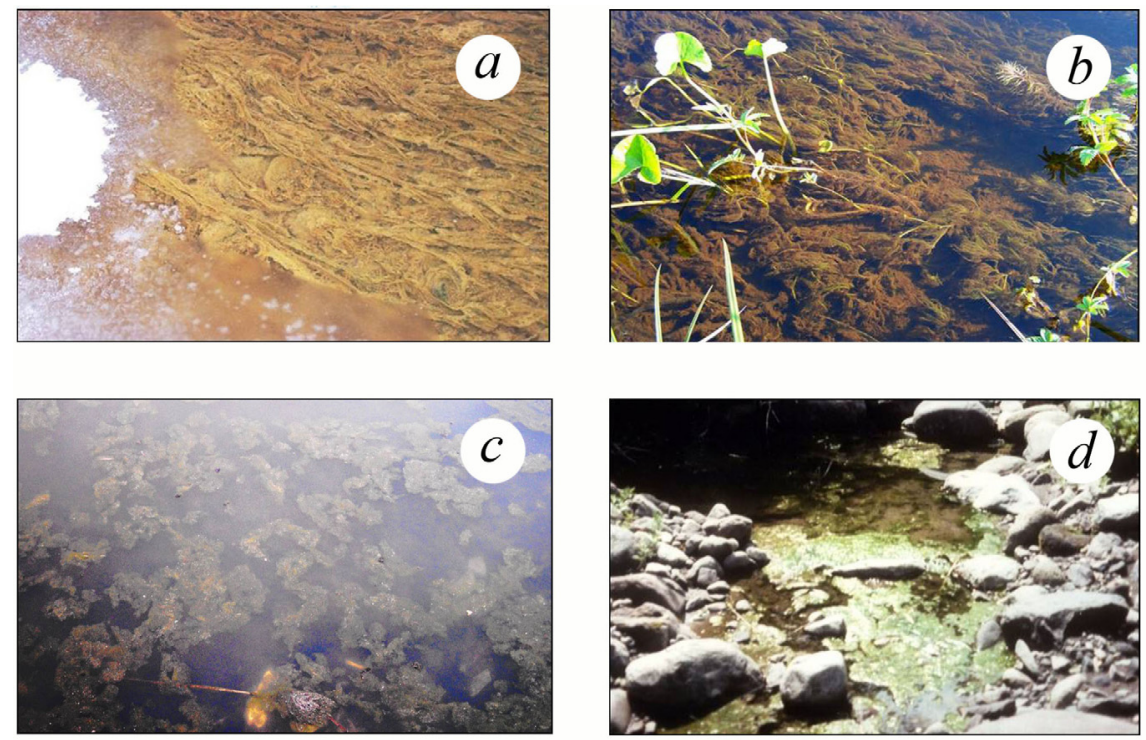

Fig. 7. Diatoms blooms on the pebble/rock bottom in the upper part of the Ussuri River in February 2013 (a); periphyton diatoms in a side channel of the Olen'ja River in June 2010 (b); metaphyton (mainly Cyanobacteria) in the low part of rivers in the southern East Manchurian Mountains in May 2014 (c); periphyton (mainly Chlorophyta and Cyanobacteria) in the open channel of stream foothills of Sikhote-Alin in June (d) (photo V. Bogatov).

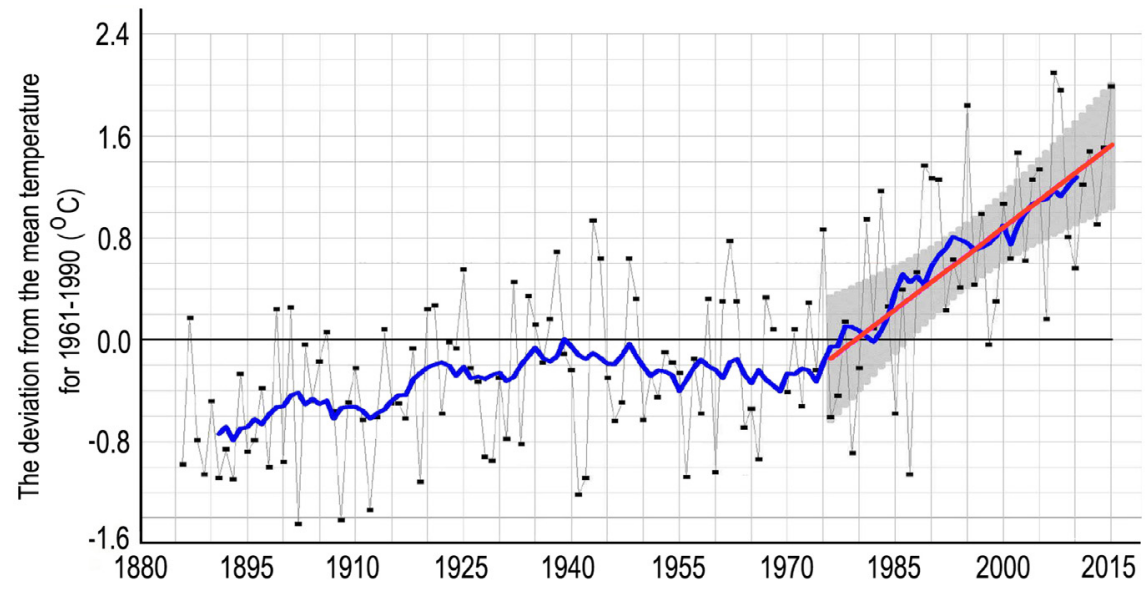

Fig. 8. The deviation of the mean annual anomalies of surface temperature averaged for the Russian Federation from 1886 to 2015 yr (Bardin et al., 2016): the anomalies were calculated as a deviation from the mean temperature during 1961-1990. The blue line shows a smoothed data (11-yr moving mean); the red line is the linear trend for 1976-2015 with a 95\% confidence interval.

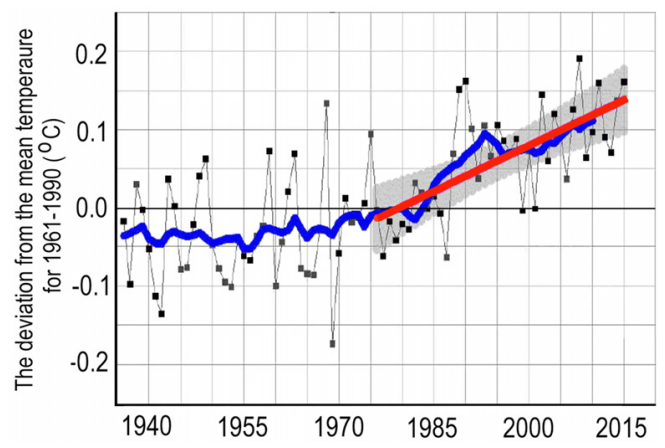

Fig. 9. The deviation of the mean annual anomalies of surface temperature averaged for the Southern Region Of the Russian Far East (SRORFE) during 1936 to $2015 \mathrm{yr}$ (Bardin et al., 2016). Notations are as in Figure 8.
For example, this region has been subjected to rare hydrological events, including extremely low water in the Amur River in 2008, extremely high flow in the southern part of the SRORFE in autumn 2012 and extreme flooding in autumn 2013 in the middle and lower region of the Amur River. The inflow volume in 2012 was $200-1000 \%$ of the mean annual flow and many rivers were covered by ice in a previously unobserved fullbank flow. The frequency of this event was estimated as once in approximately 500 to $1000 \mathrm{yr}$ (Gartsman et al., 2014), likely not as rare as the Amur River 2013 event. Hydrological extremes are nonlinear responses to climate fluctuation and may represent initial changes in the hydrological regime of the whole region.

Overall, longer droughts will increase the probability of forest fires and of low water levels in rivers and will increase 


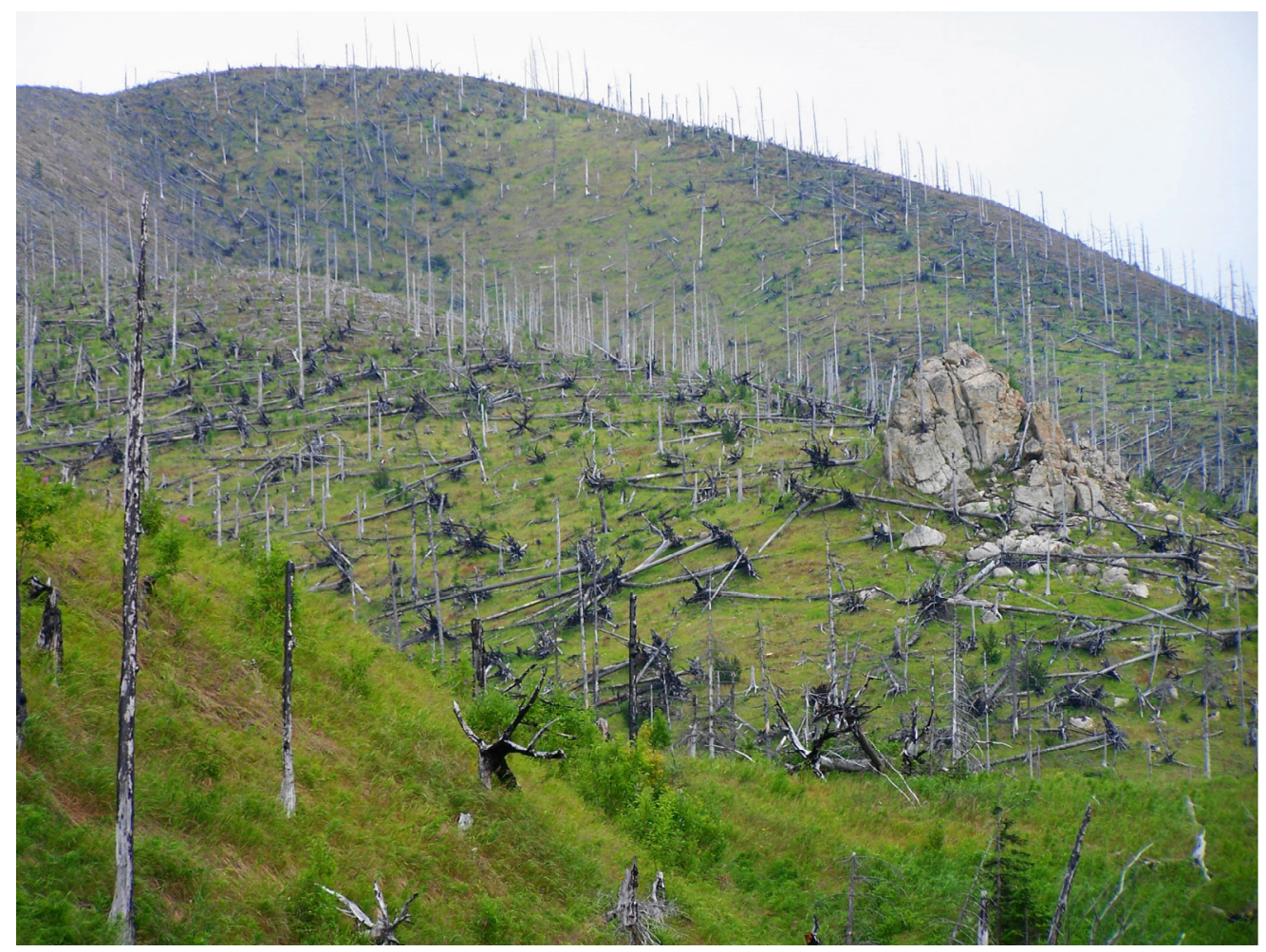

Fig. 10. Forest lands in the northern regions of the Sikhote-Alin Mountains after a large fire (photo V. Bogatov).

the nutrient load in water bodies. These impacts are particularly important for the SRORFE, the most fire-prone area in the Russian Federation. In the past 20-30 yr, the frequency of forest fire increased 30-50\% in Siberia and the Amur River Basin (Yasyukevich et al., 2014) Along the Lower Amur River, more than $60 \%$ of the basin has been affected by fire within the last 40-50 yr (Bogatov, 2014). In addition, from 1973 to 2010 the area of mass reproduction of pests in forests doubled increasing forest injury and destruction (Yasyukevich et al., 2014).

In fire-damaged areas, the water protection and soil conservation functions of forests will be considerably reduced, but the processes of steppe formation and desertification will expand (Tsvetkov and Burjak, 2014). Forest fires will result in a huge loss of forest resources (Figure 10), making streams shallower and thus negatively affecting fisheries. In watersheds where fire has already occurred, we observed intensification of erosion processes, including soil loss, increased river turbidity and a significant loss of aquatic organism diversity. Heavy floods will undoubtedly lead to the rapid depletion of the river's phytoplankton and zoobenthos in woodless territories. In addition, high water temperatures and the absence of spring flooding will cause strong spring-summer eutrophication of freshwater ecosystems.

Within forested areas, floods do not destroy river ecosystems; in contrast, periodic medium and small floods alternating with low-flow periods are beneficial to general hydrobiological regimes. This alternation is the most important factor ensuring stable and rich river ecosystems; only under these conditions can the dynamic character and high diversity of these systems be supported. Alternating patterns of hydrobiological regimes agree with the intermediate disturbance hypothesis of Grime (1973) and Connell (1978), who postulated that the highest ecosystem diversity occurs with intermediate levels of disturbance. Thus, the preservation of biodiversity and potential productivity in river ecosystems in this region is possible only by maintaining these historical natural hydrobiological regimes.

Forest communities are long-term and powerful natural regulators of streamflow within mountainous watersheds and are especially important in monsoon climates. Broad-leaved Korean pine forests, once widespread across the Sikhote-Alin Ridge, are particularly effective in this regard (Zhiltzov, 2008). Understanding the hydrological properties of forest ecosystems will help solve complex problems: water flow regulation, hydrograph stabilisation (i.e., the temporal pattern of water flow) and water resource quality improvement.

When evaluating the water protection role of forests, it is necessary to consider that the forests in the upper zone of mountains are especially vulnerable; even minor openings in the forest cover can increase the probability of devastating floods and intense erosion. Kozhevnikova and Dyukarev (2011) reported that a more than $20 \%$ disturbance of the forest cover in the southern part of the SRORFE led to a prolonged recovery of the capacity of the watershed to buffer against flooding. For mixed conifer forests, this recovery period is longer: $30-40$ yr. If the disturbance extends beyond $50 \%$ of the land cover, extensive soil erosion can occur, and restoration of the hydrological function may require more than $100 \mathrm{yr}$.

Given the global environmental change and increasing anthropogenic pressures, including deforestation, without protective measures, a significant loss of freshwater biota biodiversity in woodless territories of the SRORFE is expected. 
Acknowledgements. The authors acknowledge the following funding sources: Program of the Far Eastern Branch of the Russian Academy of Sciences "Far East", grants No. 12-1П30-01 and 15-I-6-011 o.

\section{References}

Alimov A.F., Bogatov V.V. and Golubkov S.M., 2013. Production Hydrobiology, Nauka, Saint-Petersburg, 343 p. (In Russian).

Bardin M.Y., Gruza G.V., Ran'kova E.Ya., Rocheva E.V., Platova T.V., Samokhina O.F. and Sokolov Yu.Yu., 2016. Climate change 2015 (December 2014 - November 2015). Review a state and tendency of Russia climate change, Institute of global climate and ecology, Moscow, 41 p. (Available at http://climatechange. igce.ru/index.php?option $=$ com_content $\&$ task $=$ view \&id $=34 \&$ Itemid=55\&lang=ru) (In Russian). Electronic version accessed 17.05.2016.

Bogatov V.V., 1994. Ecology of river communities of the Russian Far East, Dalnauka, Vladivostok, 218 p. (In Russian. English Summary).

Bogatov V.V., 2014. Role of the woodland vegetation in preservation of the river ecosystems biodiversity of the mountain-forest areas in the South of the Russian Far East. In: Makarchenko E.A., Bogatov V.V., Tiunova T.M., Teslenko V.A. and Medvedeva L.A. (eds.), Vladimir Ya. Levanidov's Biennial Memorial Meetings, Dalnauka, Vladivostok, Vol. 6, pp. 99-103 (In Russian).

Bogatov V.V. and Nikulina T.V., 2010. Relationship between algal communities' species diversity and catchment of rivers in the southern Russian Far East. Inland Water Biology, 3, 249-253.

Bogatov V., Sirotskiy S. and Yuriev D., 1995. The ecosystem of the Amur River. In: Cushing C.E., Cummins K.W. and Minshall G.W. (eds.), Ecosystems of the World, River and Stream ecosystems, Elsevier, Amsterdam, New York, Vol. 22, pp. 601-613.

Bogatov V.V., Miquelle D.G., Rozenberg V.A., Voronov B.A., Krasnopeev S.M. and Merril T., 2000. A biodiversity conservation strategy for the Sikhote-Alin, Far Eastern Branch Russian Academy of Science, Zov taigi, Vladivostok, $136 \mathrm{p}$.

Bogatov V.V., Nikulina T.V. and Vshivkova T.S., 2010. Relationship between the biodiversity of phyto- and zoobenthos in the continuum of the model mountain River Komarovka (Primorye, Russia). Russian J. Ecol., 41, 167-172.

Bogatov V.V., Fedorovskiy A.S. and Nikulina T.V., 2013. Role of hydrological factors in species diversity of algal communities: A case study of the Komarovka River, Primorye, Russia. Russian J. Ecol., 44, 468-474.

Bogutskaya N.G., Naseka A.M., Shedko S.V., Vasil'eva E.D. and Chereshnev I.A., 2008. The fishes of the Amur River: updated check-list and zoogeography. Ichthyol. Explor. Freshw., 19, 301366.

Boulion V.V., 1983. A primary plankton production of inland water bodies, Nauka, Leningrad, Proc. Zool. Inst. Acad. Sci. USSR, 98, $150 \mathrm{p}$.

Bushuev V.P. and Barabanstchikov E.I., 2012. Freshwater and estuarine fishes of Primorye, Dal'rybvtuz, Vladivostok, 314 p. (In Russian).

Connell J.H., 1978. Diversity in tropical rain forests and coral reefs. Science, 199, 1302-1310.

Eschmeyer W.N., Fricke R. and van der Laan R. (eds.), 2016. Catalog of fishes: genera, species, references. (Available at http:// researcharchive.calacademy.org/research/ichthyology/catalog/ fishcatmain.asp). Electronic version accessed 17.05.2016.
Fedorovskiy A.S., 1985. Formirovanie vodnykh resursov malykh rek Yuga Dal'nego Vostoka [Water resource formation in small rivers of the southern Russian Far East], Far Eastern Scientific Center of the Academy of Sciences of the USSR, Vladivostok, $124 \mathrm{p}$. (In Russian).

Gartsman B.I., Mezentseva L.I., Menovshchikova T.S., Popova N.Yu. and Sokolov O.V., 2014. Conditions of generation of extremely high water content of Primorye rivers in autumn-winter 2012. Russian Meteorology and Hydrology, 4, 260-270.

Goldman Ch.R., Kumagai M. and Robarts R.D. (eds.), 2012. Climatic Change and Global Warming of Inland Waters. Impacts and Mitigation for Ecosystems and Societies. The Atrium, Southern Gate, Wiley-Blackwell - A John Wiley \& Sons, Chichester, West Sussex (UK), Ltd., 496 p.

Grime J.P., 1973. Compeitive exclusion in herbaceous vegetation. Nature, 242, 344-347.

Jeffrey S.W. and Humphrey G.F., 1975. New spectrophotometric equations for determining chlorophylls $\mathrm{a}, \mathrm{b}, \mathrm{c}_{1}$ and $\mathrm{c}_{2}$ in higher plants, algae, and natural phytoplankton. J. Biochem. Physoil. Plants, 167, 191-194.

Khromov S.P., 1956. Mussony v global'noij atmosfernoij cirkulajcii [Monsoons in the global atmospheric circulation]. In: Budyko M.I. (ed.), A.I. Voeikov and modern problems of climatology, Hydrometeoizdat, Leningrad, 84-108 (In Russian).

Kocharina S.L., Makarchenko E.A., Makarchenko M.A., Nikolaeva E.A., Tiunova T.M. and Teslenko V.A., 1988. Donnye bespozvonochnye $\mathrm{v}$ ekosisteme lososevoy reki juga Dal'nego Vostoka SSSR [The bottom invertebrates in the ecosystem of salmon river of south Far East USSR]. In: Levanidova I.M. and Makarchenko E.A. (eds.), Fauna, Systematic and Biology of Freshwater Invertebrates, Far Eastern Branch of the Academy of Sciences of the USSR, Vladivostok, pp. 86-108 (In Russian).

Kozhevnikova N.K. and Dyukarev V.N., 2011. Ecology protective properties of high mountain zone forest cover (South of the Sikhote-Alin). Regional Environmental Issues, 4, 31-38. (In Russian).

Krestov P.V., Nazimova D.I., Stepanov N.V. and DellaSala D.A., 2011. Regional Profile: Humidity-Dependent Forests of the Russian Far East, Inland Southern Siberia, and the Eastern Korean Peninsula. In: DellaSala D.A. (ed.), Temperate and Boreal Rainforests of the World: Ecology and Conservation, ISLANDPRESS, Washington, Coledo, London, pp. 222-233.

Levanidov V.Y., 1977. Biomassa i struktura donnykh biogeocenozov reki Kedrovoiy [The biomass and structure of bottom biocenoses of Kedrovaja River]. In: Levanidov V.Y., Levanidova I.M. and Makarchenko E.A. (eds.), The Freshwater Fauna of "Kedrovaja Pad" Conservation, Far Eastern Scientific Center of the Academy of Sciences of the USSR, Vladivostok, pp. 126-158 (In Russian).

Levanidova I.M., 1982. Amfibioticheskie nasekomye gornykh oblastei Dal'nego Vostoka SSSR. Faunistika, ekologiya, zoogeografiya Ephemeroptera, Rlecoptera i Trichoptera [Amphibiotic Insects in Mountain Regions of the Far East of USSR. Fauna, Ecology, and Zoogeography of Ephemeroptera, Plecoptera, and Trichoptera], Nauka, Leningrad, 215 p. (In Russian).

Medvedeva L.A. and Sirotskiy S.E., 2002. Annotirovannii spisok vodoroslei reki Amur i vodoemov ego pridatochnoi sistemi [Annotated Checklist of Algae of the Amur River and Water Bodies of Its Basin]. In: Ivashov P.V. (ed.), Biogeochemical and Geoecological Investigations of Terrestrial and Freshwater Ecosystems, Dalnauka, Vladivostok, Vol. 12, pp. 130-218 (In Russian). 
Minshall G.W., Petersen R.W., Cummins K.W., Bott T.L., Sedell J.R., Cushing C.E. and Vannote R.L., 1983. Interbiome comparison of stream dynamics. Ecol. Monogr., 53, 1-25.

Moss B., 2010. Ecology of Freshwaters. A view for the twentyfirst century 44 edition. The Atrium, Southern Gate, Chichester, Wiley-Blackwell, West Sussex (UK) - A John Wiley \& Sons, Ltd., 433 p.

Rozenberg V.V., Dyukarev V.N. and Osipov B.A., 1993. Forest complex. In: Elyakov G.B. (ed.), Long-Term Program of Nature Conservation and Rational Use of Natural Resources in Primorye for the Period to the Year 2005 (Ecological Program). Vladivostok, Dalnauka, pp. 143-188 (In Russian).

Safonov V.V., 1979. Zooplankton in the ecosystem of the Amur River. In: Voropaev G.V. (ed.), Proc. XIV Pacific Science Congress, USSR, Khabarovsk, August 1979. Committee J. Pacific Science Association, Moscow, pp. 18-20.

SCOR-UNESCO., 1966. Report of SCOR-UNESCO working group 17. Determination of photosynthetic pigments. In: Monographs on oceanographic methodology. Determinations of photosynthetic pigments in seawater, UNESCO, pp. 9-18.

Sirotskiy S.E., 1986. Pervichnaya produkciya reki Amur i ee zavisimost' ot velichini summarnoi solnechnoi radiacii [Primary production of the Amur River and its dependence on total solar radiation value]. In: Levanidova I.M. and Bogatov V.V. (eds.), Bottom Organisms of Fresh Waters of the Far East, Far Eastern Scientific Center of the Academy of Sciences of the USSR, Vladivostok, pp. 134-140 (In Russian).

Starobogatov Ya.I., Prozorova L.A., Bogatov V.V. and Saenko E.M., 2004. Mollyuski [Mollusks]. In: Tsalolikhin S.J. (ed.), Key to Freshwater Invertebrates of Russia and Adjacent Lands]. Mollyuski, Polikhety, Nemertiny [Mollusks, Polychaetes,
Nemertines], Nauka, Saint-Petersburg, Vol. 6, pp. 9-491 (In Russian).

Strayer D.L. and Dudgeon D., 2010. Freshwater biodiversity conservation: recent progress and future challenges. J. N. Am. Benthol. Soc., 29, 344-358.

Strickland J.D.H. and Parsons T.R., 1968. A practical handbook of seawater analysis. Fish. Res. Board Can. Bull., 167, 1-311.

Tiunova T.M., 2001. Sovremennoe sostojanie i perspektivy izuchenija ekosistem lososevykh rek juga rossiyskogo Dal'nego Vostoka [The modern state and perspectives of salmon rivers of south Russian Far East studies]. In: Makarchenko E.A. and Kholin S.K. (eds.), Vladimir Ya. Levanidov's Biennial Memorial Meetings, Dalnauka, Vladivostok, Vol. 1, pp. 25-30 (In Russian).

Tiunova T.M., 2006. Trophic Structure of Invertebrate Communities in Ecosystems of Salmon Rivers in the Southern Far East. Russian J. Ecol., 37, 419-425.

Tsvetkov P.A. and Buryak L.V., 2014. The investigation of nature of Siberian forest fire. Siberian Forest J., 3, 25-42.

Yasyukevich V.V., Govorkova V.A., Korneva I.A., Pavlova T.V. and Popova E.N. (eds.), 2014. Vtoroij ocenochnyij doklad Roshydrometa ob izmenenijakh klimata i ikh posledstvijakh na territorii Rossijskoij Federacii. Obschee rezume [The second valuation Roshydromet report for climate change and its consequence on the territory of Russian Federation. The general Summary], Roshydromet, Moscow, 59 p. Available at http:// voeikovmgo.ru/download/2014/od/od2.pdf (In Russian).

Zhiltzov A.S., 2008. Gidrologicheskaya rol' gornikh khvoinoshirokolistvennikh lesov Yuzhnogo Primor'ya. [Hydrological role of mountain mixed coniferous-broad-leaved forest of south Primorye], Dalnauka, Vladivostok, 332 p. (In Russian). 